Short Communication

\section{Intensive fruit orchards cultivation}

\author{
Waleed Fouad Abobatta* \\ Horticulture Research Institute, Agriculture Research Center, Giza, Egypt
}

\section{Abstract}

The main purpose of a High-intensity cultivation system is to maximize the yield crop per area unit through planting more trees, exploiting efficient use of different resources.

There are different factors that affect high-intensity cultivation that include Land-cost, planting spaces, tree size, Rootstock, and Practice management. Meanwhile, the adoption of High-intensity cultivation to control canopy size, by using modern management practices is very crucial to get more yields in the early stages of the orchard besides simplicity in its management and increase the farmers' net profit. In addition, High-density cultivation use in different fruit crops like olive, mango, orange, mandarin, Apple, and cherry. Numerous benefits of intensive fruit cultivation include increase fruit yield per unit area, improving use efficiency of natural resources e.g. soil, light, water, and nutrients, enhancing fruit quality, improving soil properties and rising levels of organic carbon and nutrients in plant tissues ...etc. In addition, it is very effective in acid lime soil and achieves high income for the farmers.

\section{More Information}

*Address for Correspondence: Waleed Fouad Abobatta, Horticulture Research Institute, Agriculture Research Center, Giza, Egypt, Email: wabobatta@yahoo.com

Submitted: October 10, 2021

Approved: October 27, 2021

Published: October 28, 2021

How to cite this article: Abobatta WF. Intensive fruit orchards cultivation. J Plant Sci Phytopathol. 2021; 5: 072-075.

DOI: 10.29328/journal.jpsp.1001064

Copyright: (c) 2021 Abobatta WF. This is an open access article distributed under the Creative Commons Attribution License, which permits unrestricted use, distribution, and reproduction in any medium, provided the original work is properly cited.

Keywords: Canopy size; Fruit orchards; Highintensity cultivation; Productivity

D) Check for updates

OPEN ACCESS

\section{Background}

Under continuous population increasing which accompanying by global warming, there is more demand for food commodities. Furthermore, climate change conditions affect destructively on the various metabolic processes within the plant, consequently, reduce tree growth and productivity, in addition, climate change conditions increase soil deterioration, which reduces the available soil resources [1].

Achievement properly equilibrium between the trees vegetative growth and fruiting yield one of the main challenges that facing fruit grower's worldwide [2]. Therefore, there is an urgent need to maximize the utilization of the available natural resources, High-intensity cultivation (HIC) increase the efficient use of natural resources. Currently, there are a new trend in Egypt to increase efficiency use of soil, water, light, and fertilizer by increasing the number of trees planted per area, particularly with small size varieties like mandarinn (Figure 1), and Mango cv. Keitt that increases the total revenue in the first stage of orchard establishment

Moreover, HIC is essential in the case of fruit trees that have limited productive age like citrus varieties, where the farmers need to maximize production per unit area [3].

Thus, HIA could be a key solution to increase the productivity of various fruit crops particularly olive [4], and mango Rajbhar, et al. [5]. Furthermore, using dwarf rootstock increases the efficiency of high-intensity cultivation and increases fruit yield per area [6].
HIA in fruit orchards has increased exponentially since the early 1990s, (Table 1). Palesem, et al. [7] reported that HIA being over 100,000 ha olive cultivated with intensive system worldwide. Then using of intensive planting system in other crops mango [8], citrus groves [9,10], cherry [11], apple orchards [6] ...etc.

\section{Aim and scope of high-intensity cultivation}

Using HI cultivations in fruit orchards aims to increase the efficiency of water, soil, fertilizer, and light, and maximizing yield as per land unit with simplicity in orchards management [12], in addition, to provide adequate food worldwide.

Furthermore, reducing space between and within trees rows has become essential to improve conversion biomass

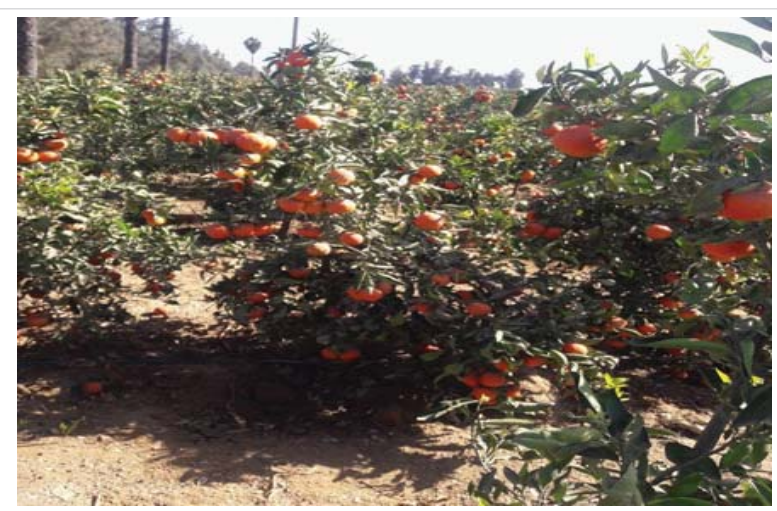

Figure 1: Mandarin orchards in Egypt (Photo by Dr. Abobatta 2018). 


\begin{tabular}{|c|c|c|c|}
\hline Crop & Scientific name & Results & References \\
\hline Olive & Olea europaea & $\begin{array}{c}\text { Enhancing yield per area unit and } \\
\text { improve fruit characters. }\end{array}$ & [4] \\
\hline Mango & Mangifera indica $\mathrm{L}$ & $\begin{array}{l}\text { Increased total yield9 to } 10 \text { times } \\
\text { more yield }\end{array}$ & [5] \\
\hline Mango & Mangifera indica $\mathrm{L}$ & & [8] \\
\hline Mango & Mangifera indica $\mathrm{L}$ & Start flowering earlier with good yield & [18] \\
\hline Mango & Mangifera indica & & {$[12]$} \\
\hline $\begin{array}{l}\text { Citrus } \\
\text { trees }\end{array}$ & Citrus spp., & Increase yield per area unit & {$[9,10]$} \\
\hline Acid lime & Citrus aurantifolia & $\begin{array}{l}\text { Increase fruit yield per area more than } \\
\text { two folds }\end{array}$ & [13] \\
\hline $\begin{array}{l}\text { Valencia } \\
\text { orange }\end{array}$ & Citrus sinensis $\mathrm{L}$. & Improving fruit quality & [17] \\
\hline $\begin{array}{l}\text { Kinnow } \\
\text { mandarin }\end{array}$ & $\begin{array}{c}\text { Citrus reticulata } \\
\text { Blanco }\end{array}$ & $\begin{array}{l}\text { Maximizing fruit weight and yield } \\
\text { per unit area and improve water use } \\
\text { efficiency. }\end{array}$ & [3] \\
\hline Cherry & Prunus cerasus & Doubling yield per area approximately. & [11] \\
\hline Apple & Malus domestica & $\begin{array}{l}\text { Increase efficiency of crop yield and } \\
\text { improve fruit quality. }\end{array}$ & [6] \\
\hline
\end{tabular}

into fruit more efficiently; in addition, narrow tree spacing is key to increasing yield per area unit and farmers' profitability.

High-intensity cultivation is beneficial particularly in fruit crops with wide canopy such as acid lime [13], and mango [8], where the vegetative growth increase annually until filling the farm-land with a few numbers trees due to wide spacing between the trees in conventional cultivation. Therefore, adequate plant spacing is the key to provide a high profit for the farmers.

Despite high establishment costs, higher production in HIA provides a proper profit for farmers. Rajbhar, etal. [5] reported that using high-density cultivation in mango groves increases yield 9 to 10 times comparing with regular cultivation.

\section{Factors that affect high-intensity cultivation}

Land-cost: Due to climate change conditions, there is a decrease in soil fertility, HIC considered the proper method to obtain success and improve the cost-effectiveness of the land units [14]. Its basic function is to increase plant number per area unit and exploit natural resources to obtain the highest total yield that can be reached from the land area [3].

Planting spaces: The fruit yield from a land unit increases proportionally to the number of the planted tree up to a certain limit. While excessive planting of trees disables photosynthesis due to reducing light reception by leaves, also, reducing fruit quality, therefore, proper utilizing of light increases total yield per area unit, improves fruit quality, and decreases the spreading of pathogens [6].

Tree size: In some cases particularly with vigor trees like orange and olive, the high-density farming system may be used during the first stage of production to obtain a quick high yield [15]. Later the trees are gradually thinned out to allow them to have a fitting canopy size that loading a high economic yield and encourages high profitability for farmers [13].
Rootstock: Rootstock choice also plays an important role since rootstocks induce or control tree growth [11]. Using dwarf rootstock under high-intensity cultivation virtually duplicate fruit yield compare with vigor rootstock [16].

Practice management: Using HIC system in mango orchards required planting dwarfing growth varieties with narrow spaces between trees and within trees rows with proper canopy management to avoid overcrowding of orchard and provide proper light penetration to get a high yield with good fruit quality [17].

\section{Benefits of high-intensity cultivation}

Using HIC system provide numerous benefits for fruit growers that include:

1. Enhancing use efficiency of available resources like soil, light, water, and nutrients.

2. Increase the crop yield per unit area.

3. Enhancing fruit quality.

4. Producing greater than 3 times soluble solids per area.

5. Reducing soil EC gradually.

6. Increasing organic carbon and nutrients particularly leaf $\mathrm{N}$ and $\mathrm{K}$ contents in HIC.

7. Under acid lime soil conditions, high-density cultivation is considered the most profitable for fruit producers.

8. Faster return of investment.

9. Increasing the farmers' net profit.

\section{Application of High-intensity cultivation}

To avoid the threatened effect of climate change on fruit orchards productivity, particularly for varieties that require manual harvesting which increases the production costs. Researchers have conducted a series of studies to evaluate the effect of various planting spacing in fruit orchards and new agricultural practices on tree growth, productivity, and fruit quality.

\section{a) Olive (Olea Europa)}

Due to climate change conditions in the past decades, olive farmers have tended to change the cultivation system with wide spacing (low intensity) to a high-intensive cultivation system, particularly in fertile soil. Furthermore, there are new dwarf varieties using for high-intensive agriculture, and modern farming techniques have been used in fertilization, irrigation, and harvesting. In addition to use, the applications of smart agriculture in farm management, which led to increasing production levels much higher than those of traditional cultivation. The surface covered by these orchards has increased exponentially since the early 1990s, 
for instance using HIC in olive orchards reaching over 100,000 ha worldwide [7].

\section{b) Mango (Mangifera indica L.)}

Currently, mango trees planting at a closer spacing in different regions worldwide like India, Egypt, South Africa, and Israel. Particularly, when using dwarf varieties that grow with small canopy size with high crop potential like Amrapali, Sadabahar, and Neelum varieties in India, Keitt, Tommy Atkins, Kent, Haden, Sensation. Nam-Dok-Mai, Duncan, Cogshall....etc [18].

However, using convention varieties in establishment mango groves with HIC system required annually removing parts of tree canopy that could reach up to more than half of canopy size after 10-11 years of tree cultivation [17].

\section{c) Orange (Citrus sinensis L.)}

The profitability of citrus orchards is threatened by climate change conditions especially increase soil salinity, consequently, increase soil degradation. Therefore, the highintensity cultivation system of citrus orchards could be the key factor that improving tree growth, increasing the total yield, and increasing farmers' profits under these conditions.

High-intensity cultivation determines the appropriate canopy size through using modern management practice and using dwarfing rootstocks to control tree vigor. Furthermore, to increase the efficiency of high-intensity cultivation in citrus groves preferable to use hedging cultivation practice by planting trees in row structures to increase light-harvesting efficiency and facilitate machinery harvesting particularly for citrus varieties that processing to produce juice like Valencia orange and Manula clementine [17].

\section{d) Mandarin}

There are different advantages of establishment highdensity orchards particularly in crops with limited productive age like kinnow mandarin, to maximizing yield, enhancing fruit quality, and improve natural resources use efficiency [3] Cherry:

The main challenge that facing cherry growers is to achieve a balance between vegetative growth and fruiting parts, through increase tree ability to form fruiting branches and cumulative yield. Therefore, the use of high-density farming balances vegetative growth and fruiting, by increasing forming flowering buds, thus increasing branches that bear fruit [11]. In addition, cherry trees that grafting on stimulant rootstocks reach the fruiting stage later than one grafted on dwarf rootstock under HIC.

More research is required to discuss the most appropriate practices for managing fruit orchards under a high-intensity cultivation system.

\section{Conclusion}

Due to the continuously increasing food demand globally, High-intensive cultivation could be a key solution to provide enough fruit production for humanity, through increase use efficiency of various resources e.g. soil, water, light, and nutrients. High-intensive cultivation could increase crop production per area unite, besides improving fruit quality to achieve higher profit for fruit growers. Intensive cultivation is used in numerous fruit crops particularly olive, mango, citrus spp., cherry, Apple...etc. in different production areas worldwide. There are numerous benefits of High-intensity cultivation like improving use efficiency of natural resources, increase productivity per unit area, improving soil properties. There are different factors influence high-intensity cultivation like Land unit cost, planting spaces, tree size, rootstock, and practice management. Therefore, there is more interesting in high-intensity cultivation particularly in fruit orchards to maximizing exploit natural resources, provide adequate production, and increase net revenue for investors in a short time.

\section{References}

1. Hall C, Dawson TP, Macdiarmid JI, Matthews RB, Smith P. The impact of population growth and climate change on food security in Africa: looking ahead to 2050. Int J Agri Sustainabi. 2017; 15: 124-135.

2. Sharma S, Rehalia AS, Sharma SD. Vegetative growth restriction in pome and stone fruits- A review. Agri Rev. 2009; 30: 13.

3. Dalal RPS, Sangwan AK, Beniwal BS, Sharma S. Effect of planting density on canopy parameter, yield and water use efficiency of Kinnow mandarin. Indian J Horticulture. 2013; 70: 587-590.

4. Fernández JE, Perez-Martin A, Torres-Ruiz JM, Cuevas MV, Rodriguez-Dominguez $\mathrm{CM}$, et al. A regulated deficit irrigation strategy for hedgerow olive orchards with high plant density. Plant Soil. 2013; 372: 279-295.

5. Rajbhar YP, Singh SD, Lal M, Singh G, Rawat PL. Performance of high density planting of mango (Mangifera indica L.) under mid-western plain zone of Uttar Pradesh. Ann Horticulture. 2016; 9: 114-116

6. Szczygiel A, Mika A. Effects of high density planting and two training methods of dwarf apple trees grown in sub-carpathian region. J Fruit Ornamental Plant Res. 2003; 11: 45-52.

7. Palese AM, Nuzzo V, Favati F, Pietrafesa A, Celano G, et al. Effects of water deficit on the vegetative response, yield and oil quality of olive trees (Olea europaea L, cv Coratina) grown under intensive cultivation. Sci Horticulturae. 2010; 125: 222-229.]

8. Singh S, Yadav GS, Hoda MN. High density planting system in 'Amrapali' mango (Mangifera indica). Indian J Agri Sci. 2001; 71: 381 383.

9. Hamido SA, Morgan KT. Effect of Various Irrigation Rates on Growth and Root Development of Young Citrus Trees in High-Density Planting. Plants. 2020; 9: 1462.

PubMed: https://pubmed.ncbi.nlm.nih.gov/33138162/

10. Hamido SA, Morgan KT. The Effect of Irrigation Rate on the Water Relations of Young Citrus Trees in High-Density Planting. Sustainability. 2021; 13: 1759.

11. Pal MD, Mitre I, Asănică AC, Sestraș AF, Peticilă AG, et al. The influence of rootstock on the growth and fructification of cherry cultivars in a high density cultivation system. Notulae Botanicae Horti Agrobotanici ClujNapoca. 2017; 45: 451-457. 
12. Kumar N. High Density Planting in Mango-Prospects and Problems. Adv Agri Res Technol J. 2019; 3: 47-53.

13. Ladaniya MS, Marathe RA, Das AK, Rao CN, Huchche AD, et al. High density planting studies in acid lime (Citrus aurantifolia Swingle). Sci Horticulturae. 2020; 261: 108935.

14. Speranza IC. Resilient adaptation to climate change in African agriculture (No. 54). Studies. 2010. https://www.econstor.eu/ handle/10419/199179

15. Abobatta WF. Canopy Management of Washington Navel Orchards under Egyptian Conditions. SunText Rev Biotechnol. 2020; 1: 107-110.

16. Fallahi E, Chun IJ, Fallahi B, Kiester MJ. New architectures and rootstocks impacts on vigor, yield efficiency, fruit quality, photosynthesis, and mineral partitioning in modern apple orchards. In I International Conference and X National Horticultural Science Congress of Iran (IrHC2017). 2017; 1315: 559-570.

17. Das B, Jana BR. Effect of canopy management on growth and yield of mango cv. Amrapali planted at close spacing. J Food Agric Environ. 2012; 10: 328-331.

18. Ahmed TB, Elkashif ME, Elamin OM. Effect of plant spacing and pruning on) vegetative growth, yield and fruit quality of introduced mango cultivars. Gezira J Agri Sci. 2014; 12: 35-50.

19. Haberman A, Dag A, Erel R, Zipori I, Shtern N, et al. Long-Term Impact of Phosphorous Fertilization on Yield and Alternate Bearing in Intensive Irrigated Olive Cultivation. Plants. 1821; 10: 1821. 